\title{
Dietary Intake of Children with Type 1 Diabetes in Bahrain: A Case- Control Study
}

\author{
Fatima Al-Haddad ${ }^{1, *}$, Abdulrahman Musaiger ${ }^{2}$, S. Mahmood Al-Qallaf ${ }^{3}$ and Kathryn Hart ${ }^{4}$ \\ ${ }^{1}$ Dietetic Unit for Hospitals, Salmaniya Medical Complex, P.O. Box 12, Manama, Kingdom of Bahrain \\ ${ }^{2}$ Nutrition and Health Studies Unit Deanship of Scientific Research, University of Bahrain, P.O. Box 32038, \\ Sakheer, Kingdom of Bahrain \\ ${ }^{3}$ Pharmacy Program, College of Health Sciences, University of Bahrain, P.O. Box 32038, Manama, Kingdom \\ of Bahrain
}

${ }^{4}$ School of Biosciences and Medicine, University of Surrey, Guilford GU2 7XH, UK

\begin{abstract}
Background \& Objectives: Bahrain is reported to rank amongst the top 10 countries for diabetes prevalence worldwide. In particular, growing numbers of children are being diagnosed with Type 1 diabetes mellitus (T1DM). The objective of this study was to describe the dietary intake of Bahraini children with T1DM as compared to a sample of healthy counterparts and to determine whether the nutrient intakes of Bahraini children with T1DM meet the current recommendations.

Design \& Setting: This was a case-control study. Dietary intake, estimated using a24-hour dietary recall, for the cases was gathered from the Pediatric Endocrine and Diabetes Unit at the Salmaniya Medical Complex and compared to the 24-hour recalls of children without diabetes recruited from Local Health Centers.

Patients \& Methods: 50 children aged 6-12 years receiving a confirmed diagnosis of T1DM in the years 2009 and 2010 compared with 55 healthy comparators.

Results: Children with T1DM consumed significantly more calories than controls $(p<0.001)$ and significantly more protein relative to their RDA $(p<0.029)$. Both groups failed to meet the RDA values for dietary fiber and for Vitamin $\mathrm{D}$. Sodium intakes were in excess of RDA values although no significant difference was observed between groups $(p=0.403)$.

Conclusion: The diets of both children with and without T1DM were found to contain excess protein and sodium and inadequate fiber, vitamin D and calcium. Children with T1DM also appeared to consume excess energy and fat. There is a need to endorse existing dietary guidelines for children with T1DM.
\end{abstract}

Keywords: Type 1 diabetes mellitus (T1DM), Children, Bahrain, Healthy diet.

\section{BACKGROUND}

Diabetes has become one of the main public health problems in the Middle East, including Bahrain. It was reported that Bahrain ranks among the top ten countries worldwide for diabetes prevalence [1]. In Bahrain, the number of children diagnosed with Type 1 diabetes mellitus (T1DM) is also on the rise having more than doubled in the past ten years, with 25 new cases of pediatric Type 1 diabetes diagnosed per 100,000 population in 2010 [2]. It is well known that cardiovascular disease (the main cause of death in Bahrain) is more prevalent among patients with T1DM than among those without diabetes [3, 4]. This is placing a significant economic burden on the health services provided by the Ministry of Health.

Type 1 diabetes is associated with an increased risk for the development of micro and macro vascular

*Address correspondence to this author at the Dietetic Unit for Hospitals, Salmaniya Medical Complex, P.O. Box 12, Manama, Kingdom of Bahrain; Tel: +973 36777166; Fax: +973 17284055; E-mail: Fhaddad@health.gov.bh, Fatima.alhaddad@gmail.com complications such as retinopathy, neuropathy, and nephropathy [5]. Managing diabetes with good nutrition by maintaining ideal body weight, optimal growth, and development can help prevent such complications [6]. Investigations in Western countries showed that children with T1DM have unhealthy dietary habits, with high intake of energy, carbohydrates, fat and low intake of several micronutrients, compared to healthy children [7-9]. Studies of the dietary intakes of children with T1DM in the Middle East are limited with most research in the region focusing on the dietary habits of those with type 2 diabetes [10].

A few studies have attempted to assess the dietary habits of children and adolescents in Bahrain [11-13], finding that these habits are characterized by low intakes of dietary fiber, milk, vegetables and fruit; and high intakes of fat, fast food and sugar-sweetened beverages. Breakfast was skipped by more than $50 \%$ of Bahraini children. However, none of these studies examined the dietary habits of children with T1DM alone or in comparison to those of healthy children. Understanding the current eating behaviors of children 
with T1DM in Bahrain is vital to inform the development of culturally appropriate education programs for this population yet this data is currently lacking. This study aimed to describe the dietary intake of Bahraini children with T1DM as compared to a sample of healthy counterparts and to determine if the nutrient intakes of Bahraini children with T1DM meet the current age and gender specific recommended intakes.

\section{METHODS}

This was a case-control study designed to assess the dietary intakes of newly diagnosed children with a confirmed diagnosis of T1DM in the years 2009 and 2010 in the Pediatric Endocrine Unit at the Salmaniya Medical Complex (SMC), the main governmental hospital in Bahrain. These children were compared to healthy controls recruited from local Health Centers across the country to allow the impact of disease to be investigated independently of other important factors like age and weight. The Health Research Committee at the Salmaniya Medical Complex and the Research Committee at Primary Health Care in Bahrain gave ethical approval for the study.

The inclusion criteria for case subjects were: The subject was registered as a confirmed case of T1DM at the Pediatric Diabetes Unit (PEU) at SMC; the subject was between 6 and 12 years of age at diagnosis; the subject was seen by a dietitian/nutritionist at the initial visit and had completed a 24-hour dietary recall (taken from the child in the presence of a parent or legal guardian); the subject was followed up at least once at the Pediatric Diabetes Unit, and the subject had a completed Diabetes Registry Form (DRF).
The control subjects were selected from 5 health centers. They were matched with case subjects by age, gender, BMI, and geographic location (Table 1). The total samples comprised 50 cases and 55 controls.

The $24 \mathrm{hr}$ recall was taken before commencing nutrition education and carbohydrate counting so that the diet recall was reflective of previous dietary habits and not of diet intake subsequent to diet education. Dietary intake was estimated using the 24-hour dietary recalls, which were analyzed using the Food Processor Software SQL version 10.70 (ESHA Research). Dietary intakes were expressed as absolute nutrient intakes and compared to the U.S Dietary Reference Intakes (DRI) [14]. Energy requirements were calculated based on the children's age, gender, height, weight, and activity level. The percent energy intake from macronutrients was compared to the Acceptable Macronutrient Distribution Range (AMDR) established based on U.S Dietary Reference Intakes (DRI) [14]. The data were then statistically analyzed using SPSS version 21 (SPSS Inc.) to compare intakes between cases and controls, using independent t-tests and Mann-Whitney tests as appropriate. A p-value of less than 0.05 was considered to be statistically significant.

\section{RESULTS}

\section{Energy and Macronutrient Intake}

The energy and macronutrients intake of children with and without T1DM are presented in Table 2. Overall $96 \%$ of the case group and $75 \%$ of the control group met their energy requirements when compared to their estimated total energy expenditure (TEE).

Table 1: Baseline Characteristic of Children with Type 1 Diabetes $(n=50)$ and Healthy Control Group $(n=55)$

\begin{tabular}{|c|c|c|c|c|c|c|}
\hline & & \multicolumn{2}{|c|}{ T1DM } & \multicolumn{2}{|c|}{ Healthy Controls } & \multirow{2}{*}{ P-Value } \\
\hline & & Median (IQR) & n (\%) & Median (IQR) & n (\%) & \\
\hline \multirow{2}{*}{ Age, years } & & 9.50 & & 9.00 & & \multirow{2}{*}{$0.074^{\mathrm{a}}$} \\
\hline & & $(2.00)$ & & $(3.00)$ & & \\
\hline \multirow{2}{*}{ Gender, \% } & Male & 50 & & 45 & & \multirow{2}{*}{$0.698^{b}$} \\
\hline & Female & 50 & & 55 & & \\
\hline BMI, percentile & & $46.90(82.40)$ & & $33.40(62.10)$ & & $0.326^{\mathrm{a}}$ \\
\hline BMI & & $15.09(6.86)$ & & $16.05(4.60)$ & & $0.521^{\mathrm{a}}$ \\
\hline \multirow{5}{*}{$\begin{array}{l}\text { Geographic Location by } \\
\text { Governorate }\end{array}$} & Muharraq & & $6(12.2)$ & & $14(25.5)$ & \multirow{5}{*}{$0.086^{b}$} \\
\hline & Capital & & $10(20.4)$ & & 7 (12.7) & \\
\hline & Northern & & $11(22.4)$ & & 19 (34.5) & \\
\hline & Central & & $21(42.9)$ & & $15(27.3)$ & \\
\hline & Southern & & $1(2.0)$ & & $0(0)$ & \\
\hline
\end{tabular}

IQR Interquartile Range, ${ }^{a}$ Mann Whitney; ${ }^{\mathrm{b}} \mathrm{Chi}$-squared. 
Table 2: Energy Intakes and Macronutrient Distributions in DM Children ( $n=50)$ and Non-DM Children ( $n=55)$ Expressed as Mean of Absolute Intake and Mean Percent Intake Relative to Age and Gender Recommended Dietary Allowance

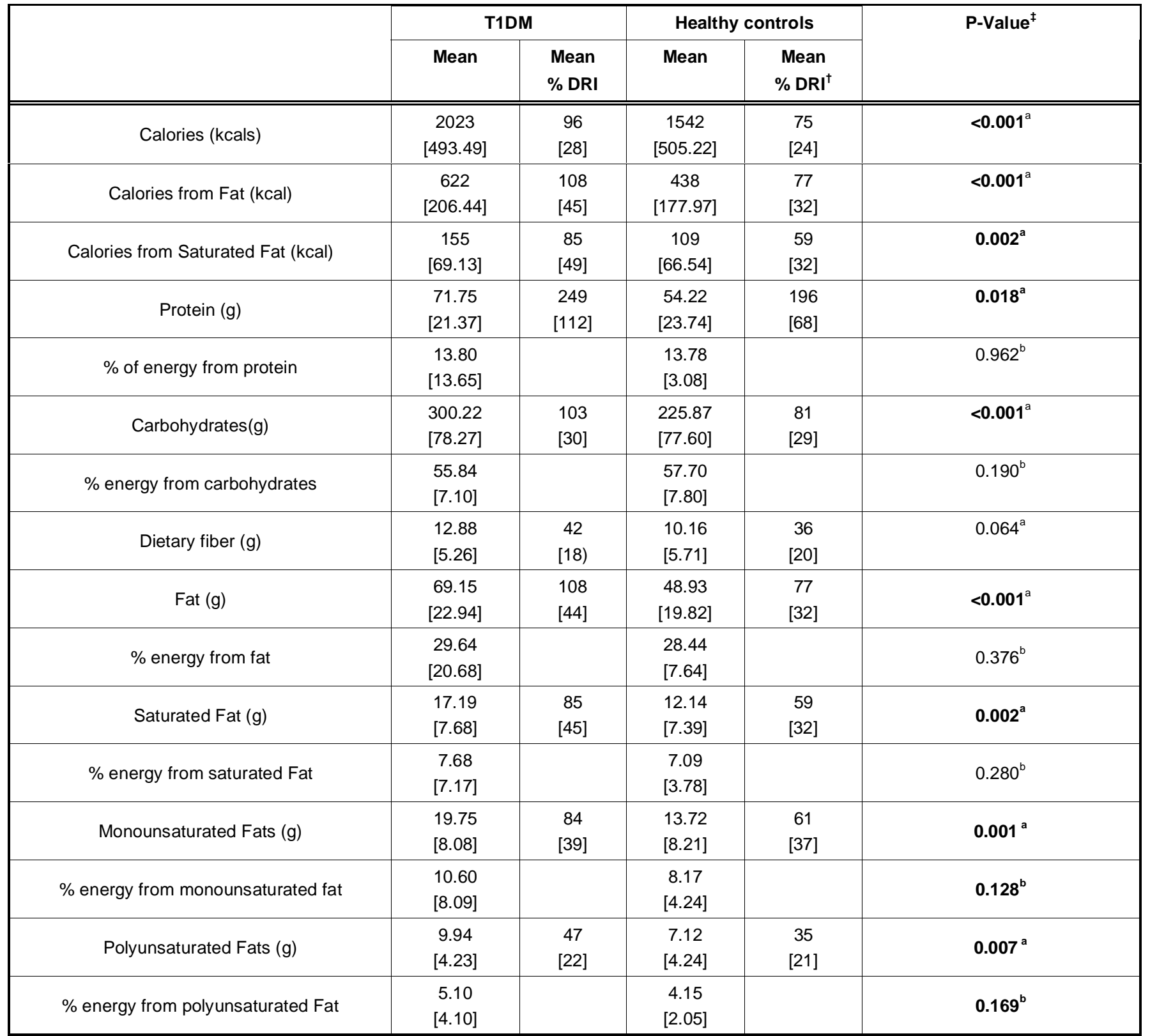

SD Standard Deviation; ${ }^{\dagger}$ Mean percent intake relative to age and gender Recommended Dietary Allowance [14] (RDA); ${ }^{a}$ Mann Whitney; ${ }^{\mathrm{b}} \mathrm{T}$-test; ${ }^{\mathrm{f}} \mathrm{P}$-value for between group comparison of \% mean RDA where available or mean absolute intake.

Children with T1DM consumed significantly more calories than controls $(p<0.001)$. They also consumed a significantly higher number of calories from fat $(p<0.001)$ and saturated fat $(p=0.002)$ than healthy children. Children with T1DM consumed about 2.5 times their RDA for protein, whereas their healthy counterparts consumed approximately twice the RDA $(p=0.018)$.

On average children with T1DM met their RDA for carbohydrates whereas healthy controls consumed a mean of 81 [SD 29] \% of their requirements $(p<0.001)$. Both groups failed to meet the RDA values for dietary fiber intake but no significant difference was observed between mean intakes when expressed as a percentage of the recommendations $(p=0.064)$.

The percent energy (\% E) intake from protein, carbohydrate and fat for the two groups is also shown in Table 2. No significant difference was observed for percent energy intake of macronutrients between the groups. Children with T1DM and healthy controls were 
within the AMDR range for macronutrients. The mean percent energy intake from polyunsaturated fats was below the recommendation in both groups and the mean percent energy intake of monounsaturated fats was slightly higher than the recommendation in children with T1DM.

\section{Vitamin Intakes}

The vitamin intakes of children with and without T1DM are presented in Table 3 . Children with T1DM consumed a significantly higher amount of vitamin B1 $(p=0.034)$, vitamin B3 $(p=0.016)$, vitamin B6 $(p=0.006)$ and vitamin $A$ (RAE) $(p=0.007)$ as compared to healthy children but this difference was no longer significant when adjusted for energy intake. Although the range of vitamin A intakes is wide, this is a true reflection of the diversity of diets within this group and specifically the high intakes of vitamin $A$ achieved by those children consuming liver; a common food in the region. After adjusting for energy vitamin $\mathrm{K}$ intake was found to be higher amongst healthy children as compared to those with T1DM ( $p=0.016)$. No significant difference was observed between the two groups for vitamin $D$ intakes, with both groups failing to meet the RDA. Both groups also failed to consume the recommended folate intake, whilst they met or exceeded requirements for vitamin C (non-significant between groups with or without energy adjustment).

\section{Mineral Intakes}

The mineral intakes of children with and without T1DM are given in Table 4. Children with T1DM had a significantly higher intake of iron $(p<0.001)$ and potassium $(p<0.001)$ as compared to their healthy counterparts. After adjusting for energy intakes, iron intake was no longer significant $(p=0.773)$ although potassium intake remained significant $(p=0.005)$. The control group met the RDA for iron but children with T1DM consumed on average 1.5 times their requirement. Potassium intakes were well below the requirements in both groups. A significant difference was observed between the groups for calcium intake

Table 3: Distribution of Vitamin Intakes between Children with and without DM $(n=50)$ and Non-DM ( $n=55)$ Group

\begin{tabular}{|c|c|c|c|c|c|}
\hline & \multicolumn{2}{|c|}{ T1DM } & \multicolumn{2}{|c|}{ Healthy Controls } & \multirow[b]{2}{*}{ P-Value } \\
\hline & $\begin{array}{c}\text { Mean } \\
\text { [SD] }\end{array}$ & $\begin{array}{c}\text { Mean } \\
\% \mathrm{DRI}^{\dagger}\end{array}$ & $\begin{array}{c}\text { Mean } \\
\text { [SD] }\end{array}$ & $\begin{array}{c}\text { Mean } \\
\% \text { DRI }^{\dagger}\end{array}$ & \\
\hline Vitamin A (RAE) & $\begin{array}{c}795 \\
{[768.88]}\end{array}$ & $\begin{array}{c}54 \\
{[34]}\end{array}$ & $\begin{array}{c}537.6 \\
{[238.47]}\end{array}$ & $\begin{array}{c}34 \\
{[27]}\end{array}$ & $0.007^{\mathrm{a}}$ \\
\hline Vitamin D (mcg) & $\begin{array}{c}0.74 \\
{[0.86]}\end{array}$ & $\begin{array}{c}15 \\
{[17)}\end{array}$ & $\begin{array}{c}0.55 \\
{[0.70}\end{array}$ & $\begin{array}{c}11 \\
{[14]}\end{array}$ & $0.061^{\mathrm{a}}$ \\
\hline Vitamin E - Alpha Tocopheral (mg) & $\begin{array}{c}2.02 \\
{[1.08]}\end{array}$ & $\begin{array}{c}21 \\
{[11]}\end{array}$ & $\begin{array}{c}1.68 \\
{[1.48]}\end{array}$ & $\begin{array}{c}19 \\
{[17]}\end{array}$ & $0.122^{\mathrm{a}}$ \\
\hline Vitamin K (mcg) & $\begin{array}{c}11.97 \\
{[13.06]}\end{array}$ & $\begin{array}{c}20 \\
{[22]}\end{array}$ & $\begin{array}{c}8.86 \\
{[19.15]}\end{array}$ & $\begin{array}{c}16 \\
{[34]}\end{array}$ & $0.001^{a}$ \\
\hline Vitamin C (mg) & $\begin{array}{l}133.66 \\
{[119.7]}\end{array}$ & $\begin{array}{c}352 \\
{[357]}\end{array}$ & $\begin{array}{c}88.84 \\
{[92.18]}\end{array}$ & $\begin{array}{c}277 \\
{[285]}\end{array}$ & $0.127^{\mathrm{a}}$ \\
\hline Vitamin B1 (mg) & $\begin{array}{c}0.94 \\
{[0.46]}\end{array}$ & $\begin{array}{l}120 \\
{[60]}\end{array}$ & $\begin{array}{c}0.70 \\
{[0.42]}\end{array}$ & $\begin{array}{c}93 \\
{[48]}\end{array}$ & $0.034^{a}$ \\
\hline Vitamin B2 (mg) & $\begin{array}{c}1.11 \\
{[0.70]}\end{array}$ & $\begin{array}{l}146 \\
{[95]}\end{array}$ & $\begin{array}{c}0.92 \\
{[0.85]}\end{array}$ & $\begin{array}{c}128 \\
{[134]}\end{array}$ & $0.0877^{\mathrm{a}}$ \\
\hline Vitamin B3 (mg) & $\begin{array}{l}13.43 \\
{[7.36]}\end{array}$ & $\begin{array}{l}127 \\
{[70]}\end{array}$ & $\begin{array}{c}9.20 \\
{[6.81]}\end{array}$ & $\begin{array}{c}95 \\
{[62]}\end{array}$ & $0.016^{a}$ \\
\hline Vitamin B6 (mg) & $\begin{array}{c}1.35 \\
{[0.60]}\end{array}$ & $\begin{array}{l}163 \\
{[83]}\end{array}$ & $\begin{array}{c}0.94 \\
{[0.62]}\end{array}$ & $\begin{array}{l}121 \\
{[74]}\end{array}$ & $0.006^{\mathrm{a}}$ \\
\hline VitaminB12 (mcg) & $\begin{array}{c}2.64 \\
{[3.57]}\end{array}$ & $\begin{array}{c}173 \\
{[211]}\end{array}$ & $\begin{array}{c}1.58 \\
{[1.86]}\end{array}$ & $\begin{array}{c}107 \\
{[116]}\end{array}$ & $0.102^{\mathrm{a}}$ \\
\hline Folate $(\mathrm{mcg})$ & $\begin{array}{c}187 \\
{[107.63]}\end{array}$ & $\begin{array}{c}71 \\
{[42]}\end{array}$ & $\begin{array}{c}137 \\
{[95.73]}\end{array}$ & $\begin{array}{c}56 \\
{[36]}\end{array}$ & $0.095^{\mathrm{a}}$ \\
\hline
\end{tabular}

SD: Standard Deviation; ${ }^{\dagger}$ Mean percent intake relative to Dietary Reference Intake (DRI); ${ }^{\text {Mann }}$ Whitney; ${ }^{\mathrm{b}} \mathrm{T}$-test; ${ }^{\ddagger} \mathrm{P}$-value for $\%$ mean RDA where available or mean absolute intakes. 
Table 4: Distribution of Mineral Intakes between Children with $(n=50)$ and without DM $(n=55)$

\begin{tabular}{|c|c|c|c|c|c|}
\hline & \multicolumn{2}{|c|}{ T1DM } & \multicolumn{2}{|c|}{ Healthy Controls } & \multirow[b]{2}{*}{ P-Value } \\
\hline & $\begin{array}{c}\text { Mean } \\
\text { [SD] }\end{array}$ & $\begin{array}{c}\text { Mean } \\
\% \text { RDA }^{\dagger}\end{array}$ & $\begin{array}{r}\text { Mean } \\
\text { [SD] }\end{array}$ & $\begin{array}{c}\text { Mean } \\
\% \text { RDA }^{\dagger}\end{array}$ & \\
\hline Calcium (mg) & $\begin{array}{c}609 \\
{[266.33]}\end{array}$ & $\begin{array}{c}56 \\
{[27]}\end{array}$ & $\begin{array}{c}411 \\
{[237.31]}\end{array}$ & $\begin{array}{c}42 \\
{[23]}\end{array}$ & $0.008^{\mathrm{a}}$ \\
\hline Iron (mg) & $\begin{array}{l}12.57 \\
{[5.57]}\end{array}$ & $\begin{array}{l}151 \\
{[65)}\end{array}$ & $\begin{array}{c}9.12 \\
{[4.97]}\end{array}$ & $\begin{array}{l}106 \\
{[63]}\end{array}$ & $<0.001^{a}$ \\
\hline Magnesium (mg) & $\begin{array}{c}143 \\
{[76.70]}\end{array}$ & $\begin{array}{c}71 \\
{[44]}\end{array}$ & $\begin{array}{c}93.99 \\
{[53.08]}\end{array}$ & $\begin{array}{c}55 \\
{[28]}\end{array}$ & $0.028^{\mathrm{a}}$ \\
\hline Phosphorus (mg) & $\begin{array}{c}903 \\
{[272.26]}\end{array}$ & $\begin{array}{c}97 \\
{[45]}\end{array}$ & $\begin{array}{c}599 \\
{[261.31]}\end{array}$ & $\begin{array}{c}81 \\
{[39]}\end{array}$ & $0.072^{\mathrm{a}}$ \\
\hline Potassium (mg) & $\begin{array}{c}1751 \\
{[859.98]}\end{array}$ & $\begin{array}{c}40 \\
{[20]}\end{array}$ & $\begin{array}{c}1025 \\
{[573.85]}\end{array}$ & $\begin{array}{c}25 \\
{[13]}\end{array}$ & $<0.001^{a}$ \\
\hline Sodium (mg) & $\begin{array}{c}2390 \\
{[1394.55]}\end{array}$ & $\begin{array}{l}138 \\
{[97]}\end{array}$ & $\begin{array}{c}1852 \\
{[1261.08]}\end{array}$ & $\begin{array}{l}114 \\
{[65]}\end{array}$ & $0.402^{\mathrm{a}}$ \\
\hline Zinc (mg) & $\begin{array}{c}6.14 \\
{[4.07]}\end{array}$ & $\begin{array}{c}90 \\
{[69]}\end{array}$ & $\begin{array}{c}4.12 \\
{[2.21]}\end{array}$ & $\begin{array}{c}65 \\
{[30]}\end{array}$ & $0.045^{\mathrm{a}}$ \\
\hline
\end{tabular}

SD Standard Deviation; ${ }^{\dagger}$ Mean percent intake relative to Dietary Reference Intake (DRI); ${ }^{a}$ Mann Whitney; ${ }^{\ddagger} \mathrm{P}$-value for $\%$ mean RDA where available or mean absolute intakes.

$(\mathrm{p}=0.008)$ with children with T1DM consuming more compared with control children, however this difference disappeared after adjusting for energy intake $(p=0.218)$. Sodium intake was in excess for both groups although no significant difference was noted between the groups $(p=0.402)$.

\section{DISCUSSION}

This study attempted to address the gap in knowledge with regards to the current dietary intakes of children with and without T1DM in Bahrain in order to inform age and culture appropriate education packages for this significant clinical population. The diets of both children with and without T1DM were found to contain excess protein and sodium and inadequate fiber, vitamin $D$ and calcium. Children with T1DM also appeared to consume excess energy and fat compared to their healthy counterparts.

Bahrain has experienced a rapid change in socioeconomic status over the past decades leading to a substantial transformation in dietary habits and lifestyle. Traditional diets which consisted of fish, vegetable, legumes and brown bread have changed to more westernized dietary patterns associated with low intakes of dietary fiber and high intakes of fat, salt and sugar [15-17]. Bahraini children are not immune to these societal shifts becoming significant consumers of fast foods and sugar-sweetened beverages, but low consumers of fruit and vegetables [11-13]. Previous researchers attempting to investigate dietary differences between children with and without diabetes in Europe have identified lower intakes of sugarsweetened soft drinks and higher intakes of fruit and vegetables among non-diabetic children compared to diabetic children [7], whilst Abdullah et al. [18] have postulated that changes in dietary habits, low intakes of foods rich in vitamin $D$ and low breastfeeding rates, might play a role in the high incidence of T1DM in Arab countries.

The results of this study show higher intakes of energy and fat among the children with T1DM, when compared with non-diabetic children. These finding are in agreement with findings from Western countries [7, $8,19]$. Excessive dietary fat is of particular concern in children with diabetes as studies have shown that people with T1DM are 10 times more likely to develop cardiovascular disease as compared to an age matched healthy population [6, 20]. Furthermore, excess intakes of fat can lead to an acceleration of blood vessel damage and a subsequent rapid progression of atherosclerosis and cardiovascular disease [21].

Fiber intake was well below the recommended RDA values in both groups. Optimal fiber intakes have been found to decrease the risk of heart disease, certain cancers and type 2 diabetes mellitus [22]. Increasing 
fiber intake can help lower blood pressure, serum cholesterol levels and has been found to be of benefit in gastrointestinal disorders such as gastroesophageal reflux disease, duodenal ulcer, diverticulitis and constipation [23]. Furthermore, an increased intake of fiber can help improve glycemic control and insulin sensitivity in individuals with diabetes [23]. The average protein intake of both children with T1DM and their healthy counterparts was higher than the requirements. Kidney disease is a major risk factor for people suffering from diabetes [24]. Consumption within the recommended dietary allowance for protein is important as an excessive intake has been associated with worsening glomerular filtration rates (GFR) in people suffering from chronic kidney disease [25]. In addition excess intakes of protein may be converted to fat which could increase the risk of obesity later in life [26].

Both groups of children had a low intake of vitamin $D$ and no significant difference was found between the two groups. This is not consistent with the findings of Bener et al., [27] who found that vitamin D deficiency was higher in children with T1DM than non-diabetic children in Qatar. Some studies have specifically linked low 25-hydroxycholcalciferol levels with the increased incidence of diabetes [28-30] with the presence of vitamin $\mathrm{D}$ receptors in the pancreas cited as a strong indicator for its role in insulin secretion and glucose tolerance [31]. It is hypothesized that vitamin D has an effect on insulin production by increasing intracellular calcium concentration which results in the secretion of insulin from the beta cells [31-33]. In a large birth cohort study, Hypponen et al. found [28] that children who were regularly supplemented with vitamin $D$ in the first year of life had a reduced risk of developing T1DM [28]. These results are supported by the EURODIAB sub-study group which found a reduction in the risk of development of T1DM in supplemented children versus non-supplemented [30]. However, in contrast, another study [29] found no association between vitamin D supplementation during the first year of life or maternal supplementation and risk of T1DM development. Failure to find an association could be due to variations in design methodologies, differences in sample size or sample population studied. Specifically the current study only assessed current intakes of vitamin $D$ in children newly diagnosed with T1DM and their nondiabetic counterparts rather than attempting to quantify early-life exposure to vitamin $D$ via diet or supplements or actual vitamin $\mathrm{D}$ status which may be influenced by factors other than diet alone. Children in both groups consumed excess sodium and had potassium intakes well below recommended levels - a combination which, in early childhood, has been linked to hypertension later in adulthood [34]. This is of particular concern in children with T1DM as raised blood pressure increases the risk of vascular damage and diabetes related complications.

The current study was limited by the use of a single 24-hour dietary recall to assess dietary intake. The authors acknowledge the possibility of under or over reporting of food consumption in 24-hour dietary recalls due to recall bias and the inability to reflect day-to-day variations in intakes. The authors also recognize that food intake at the time of diagnosis in children with T1DM could have been impacted by the symptoms of the disease itself which, aside from excessive urination, may include excessive thirst and appetite.

\section{CONCLUSION}

This study provides support for continuing to endorse the existing dietary guidelines [20] which promote increased intakes of dietary fiber, fruit and vegetables and limited intakes of fats and salt for children with T1DM. The findings of this study should be used to inform the design of future prospective and intervention trials that focus on improving the diet of both healthy children and children with T1DM. Further in-depth investigation of the factors associated with the food habits of diabetic children in the Middle East and how these may change during their disease 'journey' is urgently needed.

\section{COMPETING INTERESTS}

No competing interests to declare.

\section{REFERENCES}

[1] International Diabetes Federation (IDF) Diabetes Atlas 5th Edition, Middle East and North Africa (MENA); 2013 [updated 2014; cited 2013June 3]: Available from: http://www.idf.org/ diabetesatlas $/ 5 \mathrm{e} / \mathrm{middle}$-east-and-north-africa.

[2] Ministry of Health $(\mathrm{MOH})$. Statistic on Type 1 Diabetes in Bahrain Pediatric Endocrine \& Diabetes Clinic Salmaniya Medical Complex; 2012 [updated 2015; cited 2012 September 10]: Avilable from: http://www.moh.gov.bh/PDF/ Publications/Statistics/HS2008/PDF/CH09-smc_2008.pdf

[3] Dorman J, Laporte R, Kuller L, et al. The Pittsburgh insulindependent diabetes mellitus (IDDM) morbidity and mortality study: mortality results. Diabetes 1984; 33: 271-6. http://dx.doi.org/10.2337/diab.33.3.271

[4] Krolewski AS, Warram JH, Valsania P, Martin BC, Laffel L, Christlieb AR. Evolving natural history of coronary artery disease in diabetes mellitus. Am J Med 1991; 90: S56-S61. http://dx.doi.org/10.1016/0002-9343(91)90040-5 
[5] Nathan DM. Long-term complications of diabetes mellitus. New Eng J Med 1993; 328: 1676-85. http://dx.doi.org/10.1056/NEJM199306103282306

[6] Laing S, Swerdlow A, Slater S, et al. Mortality from heart disease in a cohort of 23,000 patients with insulin-treated diabetes. Diabetologia 2003; 46: 760-5. http://dx.doi.org/10.1007/s00125-003-1116-6

[7] Schober E, Langergraber B, Rupprecht G, Rami B. Dietary intake of Austrian diabetic children 10 to 14 years of age. $\mathrm{J}$ Pediatr Gastr Nutr 1999; 29: 144-7.

http://dx.doi.org/10.1097/00005176-199908000-00009

[8] Øverby $\mathrm{N}$, Flaaten $\mathrm{V}$, Veierød $\mathrm{M}$, et al. Children and adolescents with type 1 diabetes eat a more atherosclerosisprone diet than healthy control subjects. Diabetologia 2007; 50: 307-16. http://dx.doi.org/10.1007/s00125-006-0540-9

[9] Øverby N, Margeirsdottir H, Brunborg C, Andersen L, DahlJørgensen $\mathrm{K}$. The influence of dietary intake and meal pattern on blood glucose control in children and adolescents using intensive insulin treatment. Diabetologia 2007; 50: 2044-51.

http://dx.doi.org/10.1007/s00125-007-0775-0

[10] Al-Khudairy L, Stranges S, Kumar S, Al-Daghri N, Rees K. Dietary factors and type 2 diabetes in the middle east: what is the evidence for an association?-a systematic review. Nutrients 2013; 5: 3871-97.

http://dx.doi.org/10.3390/nu5103871

[11] Musaiger AO, Gregory WB. Dietary habits of school-children in Bahrain. Perspect Public Heal 1992; 112: 159-62. http://dx.doi.org/10.1177/146642409211200401

[12] Musaiger AO, Bader Z, Al-Roomi K, D'Souza R. Dietary and lifestyle habits amongst adolescents in Bahrain. Food Nutr Res 2011; 55.

http://dx.doi.org/10.3402/fnr.v55i0.7122

[13] Gharib N, Rasheed P. Energy and macronutrient intake and dietary pattern among school children in Bahrain: a crosssectional study. Nutr J 2011; 10: 1-12.

[14] Unites States Department of Agriculture Dietary Reference Intakes (USDA-DRI); 2014 [updated 2015 April 24; cited 2014 September 3]: Available from: http://fnic.nal.usda.gov/ dietary-guidance/dietary-reference-intakes.

[15] Musaiger AO. Changes in food consumption patterns in Bahrain. Nutr Health 1990; 6: 183-8. http://dx.doi.org/10.1177/026010609000600403

[16] Musaiger AO. The State of Food and Nutrition in Bahrain. 1993. Arabian Gulf University Press.

[17] Musaiger AO. State of nutrition in Bahrain. Nutr Health 2000; 14: 63-7. http://dx.doi.org/10.1177/026010600001400107

[18] Abdullah MA. Epidemiology of type I diabetes mellitus among Arab children. Saudi Med J 2005; 26: 911-7.

[19] Pundziūtè-Lyckå A, Persson L-Å, Cedermark G, et al. Diet, growth, and the risk for type 1 diabetes in childhood a matched case-referent study. Diabetes Care 2004; 27: 27849.

http://dx.doi.org/10.2337/diacare.27.12.2784
[20] Smart C, Aslander-van Vliet E, Waldron S. Nutritional management in children and adolescents with diabetes. Pediatr Diabetes 2009; 10(s12): 100-17. http://dx.doi.org/10.1111/j.1399-5448.2009.00572.x

[21] Nicklas TA. Dietary studies of children and young adults (1973-1988): the Bogalusa Heart Study. Am J Med Sci 199; 5310: S109.

[22] Williams CL, Bollella M, Wynder EL. A new recommendation for dietary fiber in childhood. Pediatrics 1995; 96: 985-8.

[23] Anderson JW, Baird P, Davis Jr RH, et al. Health benefits of dietary fiber. Nutr Rev 2009; 67: 188-205.

http://dx.doi.org/10.1111/j.1753-4887.2009.00189.x

[24] Levey AS, Coresh J, Balk E, et al. National kidney foundation practice guidelines for chronic kidney disease: evaluation, classification, and stratification. Ann Intern Med 2003; 139: 137-47. http://dx.doi.org/10.7326/0003-4819-139-2-200307150$\underline{00013}$

[25] Huang $\mathrm{M}-\mathrm{C}$, Chen $\mathrm{M}-\mathrm{E}$, Hung $\mathrm{H}-\mathrm{C}$, et al. Inadequate energy and excess protein intakes may be associated with worsening renal function in chronic kidney disease. J Renal Nutr 2008; 18: 187-94.

http://dx.doi.org/10.1053/j.jrn.2007.08.003

[26] Rolland-Cachera M, Deheeger M, Akrout M, Bellisle F. Influence of macronutrients on adiposity development: a follow up study of nutrition and growth from 10 months to 8 years of age. Int J Obes Relat Metab Disord 1995; 19: 573-8.

[27] Bener A, Alsaied A, Al-Ali M, et al. High prevalence of vitamin $D$ deficiency in type 1 diabetes mellitus and healthy children. Acta diabetologica 2009; 46: 183-9.

http://dx.doi.org/10.1007/s00592-008-0071-6

[28] Hyppönen E, Läärä E, Reunanen A, Järvelin M-R, Virtanen SM. Intake of vitamin D and risk of type 1 diabetes: a birthcohort study. Lancet 2001; 358: 1500-3. http://dx.doi.org/10.1016/S0140-6736(01)06580-1

[29] Stene L, Joner G. Atopic disorders and risk of childhoodonset type 1 diabetes in individuals. Clin Exp Allergy 2004; 34: 201-6. http://dx.doi.org/10.1111/j.1365-2222.2004.01864.x

[30] EURODIAB Substudy 2 Study Group. Vitamin D supplement in early childhood and risk for Type I (insulin-dependent) diabetes mellitus. Diabetologia 1999; 42: 51-4. http://dx.doi.org/10.1007/s001250051112

[31] Seshadri KG, Tamilselvan B, Rajendran A. Role of vitamin D in diabetes. J Endocr Metab 2011; 1: 47-56. http://dx.doi.org/10.4021/jem23w

[32] DeLuca HF. Overview of general physiologic features and functions of vitamin D. Am J Clin Nutr 2004; 80: 1689S-96S.

[33] Tuorkey MJ, Abdul-Aziz KK. Strategies for diabetes and pathways of vitamin D. Diabetes Metab Synd: Clin Res Rev 2010; 4: 101-10. http://dx.doi.org/10.1016/j.dsx.2009.07.010

[34] Meneely GR, Battarbee HD. High sodium-low potassium environment and hypertension. Am J Cardiol 1976; 38: 76885.

http://dx.doi.org/10.1016/0002-9149(76)90356-8 (http://creativecommons.org/licenses/by-nc/3.0/) which permits unrestricted, non-commercial use, distribution and reproduction in any medium, provided the work is properly cited. 